\title{
Critical Evaluation of Oil Palm Fresh Fruit Bunch Solid Wastes as Soil Amendments: Prospects and Challenges
}

\section{Kelechi E. Anyaoha ${ }^{a}$, Ruben Sakrabani ${ }^{a}$, Kumar Patchigolla ${ }^{b}$ and Abdul M. $\underline{\text { Mouazen }^{*}}$}

${ }^{\text {aC}}$ Cranfield Soil and Agrifood Institute, School of Water, Energy and Environment, MK43 OAL, United Kingdom

bPower Engineering Centre, Cranfield University, MK43 0AL United Kingdom, 'Department of Soil Management, Ghent University, Coupure 653, 900 Gent, Belgium. *E-mail of corresponding author: Abdul.Mouazen@UGent.be

\section{Abstract}

Sustainable land use has been identified as one way of tackling challenges related to climate change, population expansion, food crisis and environmental pollution. Disposal of oil palm fresh fruit bunch (FFB) solid wastes is becoming a challenge with an increased demand and production of palm oil. Whilst this poses a challenge, it could be turned into an opportunity by utilising it as a resource and fully valorise it to meet soil and crop demands. This review presents the potentials of FFB solid wastes, which include empty fruit bunch (EFB), mesocarp fibre (MF), palm kernel shell (PKS), as soil ameliorants. The major findings are the following: 1) pyrolysis, gasification, combustion, and composting are processes that can enhance the value of FFB solid wastes. These processes lead to new products including biochar, ash, and compost, which are valuable resources that can be used for soil improvement. 2) The application of EFB mulch, ash from EFB, MF and PKS, biochar from EFB, and PKS, and compost of EFB, and MF led to improvement in soil physico-chemical properties, and growth and performance of sweet corn, mushroom, oil palm, sweet potato, cauliflower plant, banana, maize, cocoa, cassava, eggplants, and pepper. However, reports show that EFB compost and ash led to decrease in 
growth and performance of okra. Therefore, the use of appropriate conversion technology for FFB solid wastes as soil ameliorants can significantly improve crop yield and soil properties, reduce environmental pollution, and more importantly increase income of oil mill processors and savings for farmers.

Keywords: Empty fruit bunch, Palm kernel shell, Mesocarp fibre, Ash, biochar, Soil

\section{Introduction}

Agricultural productivity and land conservation are important for the sustainability of humanity. With an increasing demand for food due to increasing population, an integrated sustainable approach needs to be adopted to ensure that agricultural production does not impinge negatively on land resources. To ensure there is continuous supply of food and fibre without depleting the land resources, one approach to replenish nutrients can be through the application of organic amendments. Lack of resources limit soil conservation practices and therefore efforts are being made towards deriving greater values from available organic materials. Organic amendments have gained interest due to the high cost of inorganic fertilisers and the adverse effects of its continuous usage on soil. However, inefficient use of organic amendments can pose significant environmental challenges such as eutrophication of water bodies and leachate affecting groundwater. Applying these amendments to the soil in an optimum manner can result in an increase in soil organic matter, which improves soil fertility and minimises soil degradation (Rickson et al., 2015).

African oil palm (Elaeis guineensis) is believed to originate from West Africa and today is widely grown in most parts of West and Central Africa, Southeast Asia, and South America. Oil palm is a single stemmed tree and can grow to a height of more than 30 metres (Ibitoye and Onje, 2013; Jagustyn et al., 2013). The fruit bunch can weigh up to $25 \mathrm{~kg}$ and contain as much as 1000 fruits (Ibitoye and 
57 Onje, 2013; Jagustyn et al., 2013). The oil palm tree is the major source of plant oil in the tropical region.

59 Palm oil is produced by processing oil palm fresh fruit bunch (FFB), which leads 60 to the generation of FFB solid wastes. Notable FFB solid wastes are empty fruit 61 bunch (EFB), mesocarp fibre (MF), and palm kernel shell (PKS) while palm oil 62 mill effluent is the liquid wastes (Figure 1). Other residues and/by-products processed from FFB solid wastes are in the form of ash, biochar, and compost. The major producers of palm oil are Indonesia, Malaysia, Thailand, Colombia and Nigeria according to Index mundi (2017), contributing $92 \%$ of global production (Figure 2). An estimated 1.65 million hectares of oil palm is spread over Nigeria (Olagunju, 2008), while there are over 4 million and 7 million hectares of oil palm in Malaysia and Indonesia, respectively (Sulaiman et al., 2011). Anyaoha et al. (2018) reported that the total FFB solid wastes produced in 2014 was 75 million tonnes, and that the figure is equivalent to 23 million tonnes of EFB, 21 million tonnes of MF, and 7.5 million tonnes of PKS. 


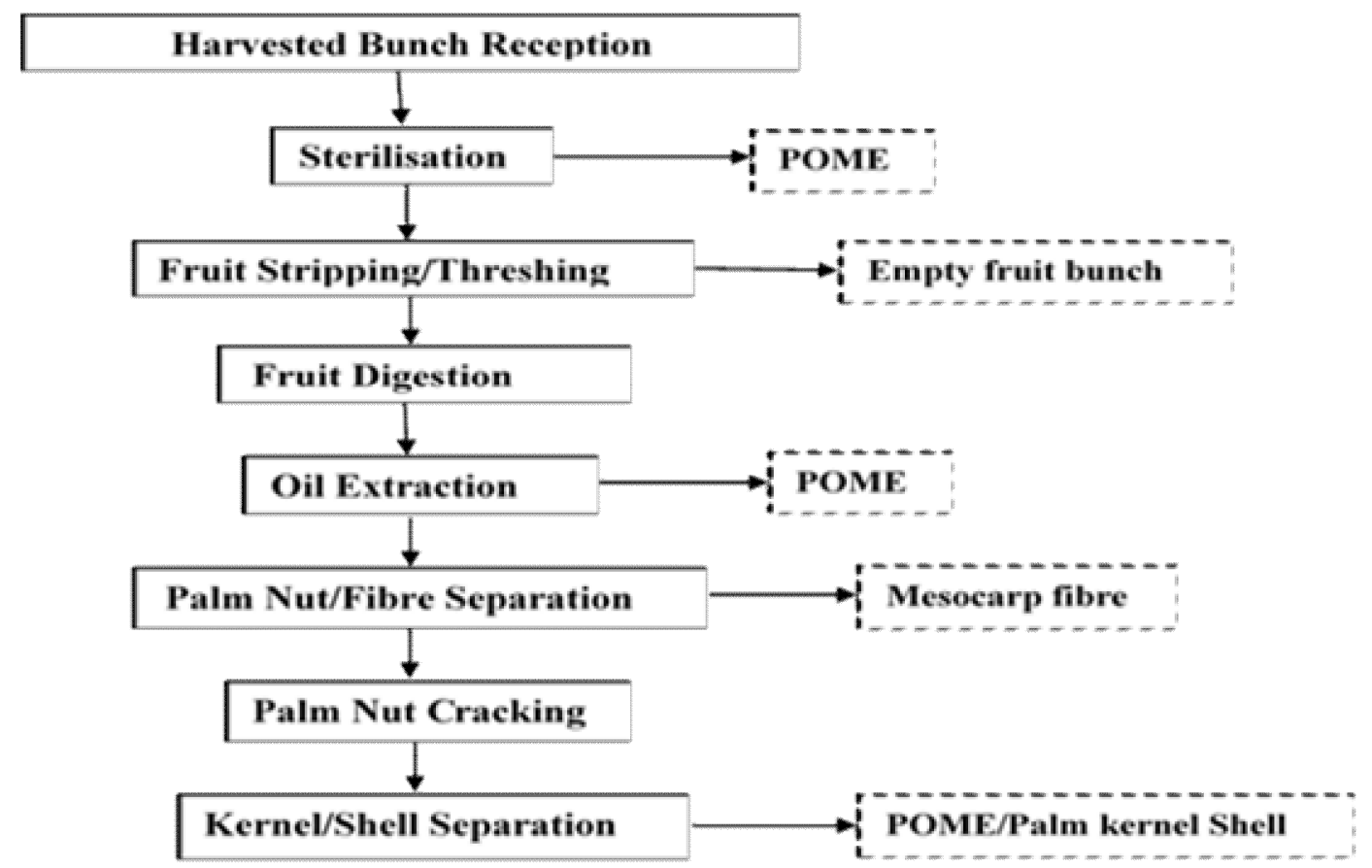

Figure 1 Flow chart of fresh fruit bunch processing showing points of generation of wastes. Solid boxes are the process, while dashed boxes represent wastes. POME - palm oil mill effluent.

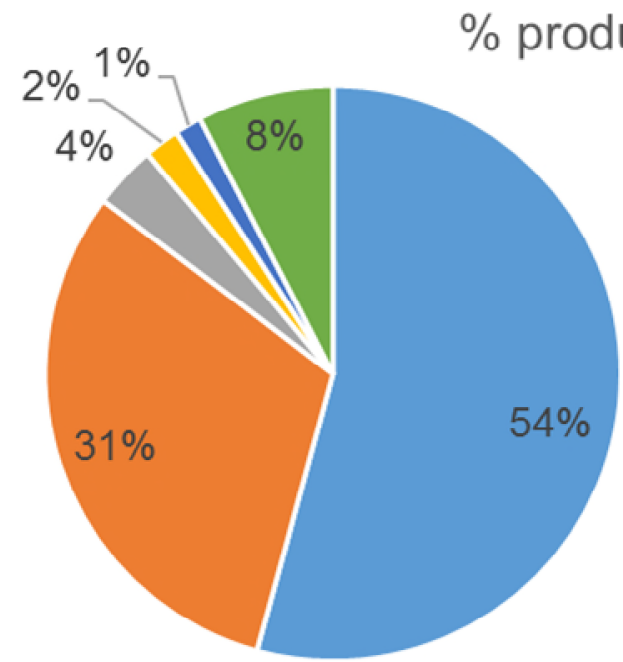

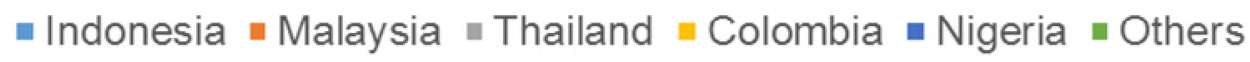

Figure 2 Global percentage of palm oil production (Source: Index Mundi, 2017). 
This paper aims to present a critical evaluation of the value of FFB solid waste streams (EFB, MF, PKS, ash, biochar and compost) and their benefits for crop performance and soil quality improvement, when used as organic amendments. Specifically, the following will be reviewed: (i) the current progress on the soil applications of FFB solid waste by-products (ash, biochar, and compost) derived from thermal and biological conversions of EFB, MF, and PKS, and (ii) the agronomical and environmental impacts of FFB solid waste streams utilisation, providing bases for strategic development needs.

\section{Fresh fruit bunch solid waste streams}

There are variations in the physical and chemical characteristics of FFB solid wastes. Apart from the potential differences due to geography and the soil where the trees are grown, oil palm tree differs due to the thickness of the shells (varieties), and on the quality of the FFB. Dura variety is known for its thick shell and thin mesocarp, Pisifera variety is known to be shell-less, while Tenera variety has a thicker mesocarp and thinner shell (Asadullah et al., 2014). In Nigeria, most palm oil mills process a mixture of the three varieties. Higher quality FFB produces relatively more fruits compared to the size of the EFB, a tree can produce varying bunch (high and low-quality). These variations influence the weight of EFB, PKS, and MF per FFB. Tables 1,2 and 3 summarise the characteristics of EFB, MF and PKS, respectively. 
Table 1 Proximate and ultimate analysis and heating values of empty fruit bunch (EFB) from literature.

\begin{tabular}{|c|c|c|}
\hline Analysis & Literature & References \\
\hline & $\mathrm{db}$ & \\
\hline \multicolumn{3}{|l|}{ Proximate (wt.\%) } \\
\hline Volatile matter & $67.59-83.86$ & Idris et al. (2015); Lahijani et al. (2013); Sulaiman and Abdullah (2011) \\
\hline Fixed carbon & $8.36-21.80$ & Idris et al. (2015); Lahijani et al. (2013); Lahijani and Zainal (2011) \\
\hline Moisture content & $5.18-8.31$ & Idris et al. (2015); Lahijani et al. (2013); Mohammed et al. (2012); Omar et al. (2011) \\
\hline Ash & $3.45-7.54$ & Idris et al. (2015); Lahijani et al. (2013); Mohammed et al. (2012); Omar et al. (2011) \\
\hline \multicolumn{3}{|r|}{ (2) } \\
\hline Carbon & $43.52-49.07$ & $\begin{array}{l}\text { Idris et al. (2015); Lahijani et al. (2013); Lahijani and Zainal (2011); Sulaiman and } \\
\text { Abdullah (2011) }\end{array}$ \\
\hline Hydrogen & $5.72-6.48$ & $\begin{array}{l}\text { Idris et al. (2015); Lahijani et al. (2013); Lahijani and Zainal (2011); Sulaiman and } \\
\text { Abdullah (2011) }\end{array}$ \\
\hline Nitrogen & $0.25-1.65$ & Idris et al. (2015); Lahijani et al. (2013); Mohammed et al. (2012); Omar et al. (2011) \\
\hline Sulphur & $0.04-1.06$ & Idris et al. (2015); Lahijani et al. (2013); Mohammed et al. (2012); Omar et al. (2011) \\
\hline Oxygen* & $38.29-48.9$ & $\begin{array}{l}\text { Idris et al. (2015); Lahijani et al. (2013); Lahijani and Zainal (2011); Sulaiman and } \\
\text { Abdullah (2011) }\end{array}$ \\
\hline \multicolumn{3}{|l|}{ Lignocellulose (wt.\%) } \\
\hline Cellulose & $13.75-59.70$ & Idris et al. (2015); Mohammed et al. (2012) Sulaiman and Abdullah (2011) \\
\hline Hemicellulose & $12.79-22.10$ & Idris et al. (2015); Mohammed et al. (2012) Sulaiman and Abdullah (2011) \\
\hline Lignin & $7.79-30.45$ & Idris et al. (2015); Mohammed et al. (2012) Sulaiman and Abdullah (2011) \\
\hline $\mathrm{HHV}(\mathrm{kJ} / \mathrm{kg})$ & $15220-19350$ & $\begin{array}{l}\text { Anyaoha et al. (2018); Idris et al. (2015); Lahijani and Zainal (2011); Sulaiman and } \\
\text { Abdullah (2011) }\end{array}$ \\
\hline Bulk density $\left(\mathrm{kg} / \mathrm{m}^{3}\right)$ & $110-144$ & Anyaoha et al. (2018); Sung et al. (2010) \\
\hline
\end{tabular}


Table 2 Proximate and ultimate analysis, and heating values of mesocarp fibre (MF) from literature.

\begin{tabular}{|c|c|c|}
\hline \multirow[t]{2}{*}{ Analysis } & \multicolumn{2}{|l|}{ Literature } \\
\hline & $\mathrm{db}$ & References \\
\hline \multicolumn{3}{|l|}{ Proximate (wt.\%) } \\
\hline Volatile matter & $67-79$ & Khanday et al. (2016); Wilson et al. (2011) \\
\hline Fixed carbon & $9.3-28$ & Khanday et al. (2016); Wilson et al. (2011) \\
\hline Moisture content & $4.98-5$ & Khanday et al. (2016); Wilson et al. (2011) \\
\hline Ash & $1-11.8$ & Khanday et al. (2016); Wilson et al. (2011)) \\
\hline \multicolumn{3}{|l|}{ Ultimate (wt.\%) } \\
\hline Carbon & $30.02-52.2$ & Harimi et al. (2005); Khanday et al. (2016); Wilson et al. (2011) \\
\hline Hydrogen & $3.81-11$ & Harimi et al. (2005); Khanday et al. (2016); Wilson et al. (2011) \\
\hline Nitrogen & $0.7-1$ & Harimi et al. (2005); Khanday et al. (2016); Wilson et al. (2011) \\
\hline Sulphur & $0.07-1$ & Harimi et al. (2005); Khanday et al. (2016); Wilson et al. (2011) \\
\hline Oxygen** & $23.35-42$ & Harimi et al. (2005); Khanday et al. (2016); Wilson et al. (2011) \\
\hline Chlorine & 0.06 & Wilson et al. (2011) \\
\hline \multicolumn{3}{|l|}{ Lignocellulose (wt.\%) } \\
\hline Cellulose & 40 & Khanday et al. (2016) \\
\hline Hemicellulose & 20 & Khanday et al. (2016) \\
\hline Lignin & 30 & Khanday et al. (2016) \\
\hline $\mathrm{HHV}(\mathrm{kJ} / \mathrm{kg})$ & $19331-21980$ & $\begin{array}{l}\text { Anyaoha et al. (2018); Harimi et al. (2005); Khanday et al. (2016); } \\
\text { Wilson et al. (2011) }\end{array}$ \\
\hline Bulk density $\left(\mathrm{kg} / \mathrm{m}^{3}\right)$ & 225 & Anyaoha et al. (2018) \\
\hline
\end{tabular}


Table 3 Proximate and ultimate analysis, heating values of palm kernel shell (PKS) from literature.

\begin{tabular}{|l|l|l|}
\hline \multicolumn{2}{|l|}{ Analysis } & Literature \\
\hline \multicolumn{2}{|l|}{ db } \\
\hline Proximate (wt.\%) & References \\
\hline Volatile matter & $53.38-77.5$ & Jamaluddin et al. (2013); Wilson et al. (2011); Zainal et al. (2016) \\
\hline Fixed carbon & $18.84-20.3$ & Jamaluddin et al. (2013); Wilson et al. (2011); Zainal et al. (2016) \\
\hline Moisture content & $8.4-9.55$ & Wilson et al., (2011); Zainal et al., (2016 \\
\hline Ash & $0.87-4.6$ & Jamaluddin et al. (2013); Wilson et al. (2011); Zainal et al. (2016) \\
\hline Ultimate (wt.\%) & $43.8-60.9$ & Harimi et al. (2005); Wilson et al. (2011); Zainal et al. (2016) \\
\hline Carbon & $5.27-12.76$ & Harimi et al. (2005); Wilson et al. (2011); Zainal et al. (2016) \\
\hline Hydrogen & $0.36-0.66$ & Harimi et al. (2005); Wilson et al. (2011); Zainal et al. (2016) \\
\hline Nitrogen & $0.03-0.19$ & Harimi et al. (2005); Wilson et al. (2011); Zainal et al. (2016) \\
\hline Sulphur & $31.18-37.7$ & Harimi et al. (2005); Wilson et al. (2011) \\
\hline Oxygen* & 0.05 & (Wilson et al. (2011) \\
\hline Chlorine & 27.7 & Zainal et al. (2016) \\
\hline Lignocellulose (wt.\%) & Zainal et al. (2016) \\
\hline Cellulose & 21.6 & Zainal et al. (2016) \\
\hline Hemicellulose & 44 & Anyaoha et al. (2018)Harimi et al. (2005); Wilson et al. (2011); Zainal et al. (2016) \\
\hline Lignin & $17930-20520$ & Anyaoha et al. (2018); Arzola et al. (2012) \\
\hline HHV (kJ/kg) & $715-780$ &
\end{tabular}

115 All in wt.\% except where it is stated otherwise. db - dry basis, HHV - high heating value, *by difference 
EFB is generated when the fruits are removed from the FFB. It can appear in different forms depending on how the FFB is processed, which differs particularly in Nigeria with the generation of empty fruit spikelet (EFS), and bunch stalk (BS) separately by the subsistence (traditional processing) palm oil millers (Anyaoha et al., 2018). The chaff is the additional part of the EFB. The chaff is found at the base where each fruit is attached to the spikelet and tends to separate itself from the spikelet when dry. The chaff comprises of about $0.9-$ $2.4 \%$ of FFB (Ohimain et al., 2013). The EFB is generated at the palm oil mills with very high moisture content of up to $60 \%$ (Tabi et al., 2008). Relative to MF, and PKS, EFB has a very low bulk density, which makes its transportation difficult (Tables 1, 2 and 3).

The MF or palm press fibre results from the oil bearing mesocarp after the extraction of oil and separation of the pulp (palm nut/mesocarp fibre mixture). The oil is extracted by washing the pulp with steam or by pressing. The MF makes up about $14-28.1 \%$ of FFB (Ohimain et al., 2013; Omar et al., 2011; Sulaiman and Abdullah, 2011).

The palm nut or the endocarp is the hard part of the oil palm fruit covering the oil-bearing palm kernel. The palm nut when cracked takes varying shapes and sizes because of the cracking force and the resulting product is called PKS. When compared to EFB and MF, PKS has lower moisture content, and higher lignin and bulk density (Tables 1, 2 and 3).

The availability of MF and PKS as better biomass fuels makes the application of EFB to oil palm plantations the best option. The BS (82.6\%) of higher moisture content than that of the EFS (57.5\%) according to Omar et al. (2011) limits the use of EFB as fuel. The Conversion FFB solid waste streams into forms ready for use as soil ameliorants is as important as the availability of the wastes. Other than direct application, pyrolysis, gasification, combustion, and composting are well-researched technologies of valorising FFB solid wastes. These technologies lead to the production of ash, biochar, and compost, which are important soil amendments that will be discussed in the following sections. 


\subsection{Ash}

147 In palm oil mills, ash is generated in the form of fly ash, bottom ash, and slag when FFB solid wastes are combusted especially MF and PKS. The estimated global production of FFB solid wastes was 57 million tonnes in 2014, therefore EFB, MF and PKS ash were 1.2 million tonnes, 1.1 million tonnes, and 0.1 million tonnes, respectively. The estimates are based on the ash contents of EFB, MF, and PKS dry basis of $5.1,5.5$, and 1.7 wt.\%, respectively as determined according to British Standards Institute (2011). A significant difference between the ash from the three solid biomass is the higher content of alkali found in EFB (Abdullah and Sulaiman, 2013). Ash has been found to be very useful in many ways but the specific increase in its agricultural use has become of special interest due to the high nutrient content for soil amelioration and crop improvement.

Gasification and combustion are important thermal conversion processes leading to the generation of ash as residue. Gasification is a partial oxidation process that is used to produce fuel gas (Puig-Arnavat et al., 2010). Most palm oil mills rely on the combustion of MF and PKS for heat and power generation, and therefore, the production of ash is an integral part of FFB processing and valorisation of the wastes for soil use.

Most investigations on the gasification (Ogi et al., 2013) and combustion (Idris et al., 2012) of FFB solid wastes focused on the fuel value with limited consideration on the optimization of the residue yield for agricultural purposes (for example soil amelioration, and consequently crop growth and yield), even though the residue is an important part of the processes and can affect the overall performance of the systems.

\subsection{Biochar}

Biochar is produced during pyrolysis after the moisture and volatiles have been removed at an elevated temperature. Biochar remains an important output of pyrolysis representing up to $35 \%$ of PKS (palm shell), $29 \%$ EFB, and $30 \% \mathrm{MF}$ 
175 (Abnisa et al., 2013) of the wastes under pyrolysis. Expectedly, the highest biochar yield of EFB was recorded at pyrolysis temperature of $300{ }^{\circ} \mathrm{C}$ and the lowest at $700{ }^{\circ} \mathrm{C}$ (Sukiran et al., 2011) similar to figures by Claoston et al. (2014) of $38 \%$ at $350{ }^{\circ} \mathrm{C}$ and $21 \%$ at $650{ }^{\circ} \mathrm{C}$.

The mineral components retained in biochar during pyrolysis makes it a valuable soil amendment (Lee et al., 2017a; Mašek et al., 2010; Xu et al., 2017;). Zhao et al. (2013) reported that the biochar surface area, its carbon recalcitrance, and high nutrient content determine its application.

Biochar prevents water contamination and soil erosion, and by its absorbing characteristics due to large surface area, the ability of the soil to retain moisture and nutrients increases (Abnisa et al., 2013). Biochar could ameliorate soil quality, reduce fertiliser consumption, and sequestrate carbon (Lee et al., 2013). The Brunauer-Emmett-Teller (BET) measures the surface area of the biochar. Temperature and ash content have been reported to influence BET surface area (Claoston et al., 2014; Nam et al., 2018; Shariff et al., 2014). Nam et al. (2018) reported BET surface area for PKS of $100 \mathrm{~m}^{2} / \mathrm{g}$ at $550{ }^{\circ} \mathrm{C}, 155 \mathrm{~m}^{2} / \mathrm{g}$ at $650{ }^{\circ} \mathrm{C}$, and $270 \mathrm{~m}^{2} / \mathrm{g}$ at $750{ }^{\circ} \mathrm{C}$. Claoston et al. (2014) found that the temperature of $650^{\circ} \mathrm{C}$ led to the highest BET surface area of $28 \mathrm{~m}^{2} / \mathrm{g}$ compared to temperatures of $500{ }^{\circ} \mathrm{C}\left(15 \mathrm{~m}^{2} / \mathrm{g}\right)$ and $350{ }^{\circ} \mathrm{C}\left(12 \mathrm{~m}^{2} / \mathrm{g}\right)$ for EFB of $<2 \mathrm{~mm}$ with the operation lasting for $2 \mathrm{~h}$. Lee et al. (2017a) reported a BET value of 191 $\mathrm{m}^{2} / \mathrm{g}$ at $500{ }^{\circ} \mathrm{C}$ for PKS, $2.71 \mathrm{~m}^{2} / \mathrm{g}$ at $350-450{ }^{\circ} \mathrm{C}$ was reported for EFB (Harsono et al., 2013), $0.13 \mathrm{~m}^{2} / \mathrm{g}$ at $550{ }^{\circ} \mathrm{C}$ for EFB (Shariff et al., 2014) while Abdulrazzaq et al. (2015) reported a value of $12.2 \mathrm{~m}^{2} / \mathrm{g}$ at $300-350{ }^{\circ} \mathrm{C}$ for EFB. The EFB ash contents of $5.29,4.65,3.28,2.21$, and $1.60 \mathrm{wt} \%$ led to increase in BET of approximately 0.13, 0.38, 9.25, 11.12, and $7.99 \mathrm{~m}^{2} / \mathrm{g}$, respectively. There was increase in BET as ash content reduces except with the 1.60 wt. $\%$ value.

Idris et al. (2014) reported 210, 186, and $145 \%$ more Ca, K, and $\mathrm{Ca}$ in EFB biochar than raw EFB making biochar a more valuable soil amendment. Similarly, $\mathrm{K}$ increased with temperature $\left(4 \mathrm{wt} . \%\right.$ at $350{ }^{\circ} \mathrm{C}$ and $7 \mathrm{wt} . \%$ at $\left.650{ }^{\circ} \mathrm{C}\right)$ 
205 (Claoston et al., 2014). Compared to wood bark (4736 ppmw) and paddy straw 206 (1956 ppmw), Lee et al. (2013) demonstrated that PKS biochar (21,380 ppmw) contains higher concentration of iron and tends to be more acidic with $\mathrm{pH}$ of 6.9 compared to 9.6 and 10.5 of wood bark and paddy straw, respectively. The low $\mathrm{pH}$ was attributed to lower alkali and alkali earth metals in PKS. Kabir et al. (2017) demonstrated that MF biochar contains significantly higher ash content (27\%) than that of palm frond (4\%), while the $\mathrm{K}$ and Ca contents of MF are 22 $\%$ and $9 \%$ compared to that of palm frond of $46 \%$ and $16 \%$, respectively. The pyrolysis was carried out in a slow heating bed-reactor of a temperature of 550 ${ }^{\circ} \mathrm{C}$, heating rate of $10{ }^{\circ} \mathrm{C} / \mathrm{min}$, and a nitrogen flow rate of $200 \mathrm{ml} / \mathrm{min}$. The $\mathrm{K}$ and Ca contents of PKS biochar were $1.105 \%$ and $5.25 \%$ (Kim et al., 2010) whereas Bazargan et al. (2014) reported values of $29.8 \%$ and $41.4 \%$, respectively.

Mašek et al. (2010) defined two biochar fractions as stable and non-stable, which differentiate how long the biochar will sequestrate and demonstrated that the yield of the stable fraction of biochar is not dependent on pyrolysis temperature. The biochar adds to the carbon content of the soil and suppresses the release of greenhouse gases from the soil. Biochar has a higher calorific value than raw fuel (Bazargan at al., 2014). For example, raw MF and biochar from the MF pyrolysis have calorific values of 18760 , and $23540 \mathrm{~kJ} / \mathrm{kg}$, respectively (Hooi et al., 2009). Harsono et al. (2013) investigated energy balances, greenhouse gas emissions and economics of biochar production and demonstrated that the production of biochar from slow pyrolysis of EFB is economically feasible and technically viable. Xu et al. (2017) reported that the properties of biochar are very important in its effectiveness. The biochar is therefore a valuable fuel, which will lead to ash production either through gasification or combustion (Kimble et al., 2008). Table 4 is the characteristics of biochar from EFB, MF, and PKS (Abnisa et al., 2013; Nam et al. (2018). 


\subsection{Compost}

234 Compost is produced from the decomposition of organic matter through the process of composting. Important considerations in composting are degradation rate and the quality of the final compost (Rupani et al., 2010). Composting efficiency is measured by the carbon-nitrogen $(\mathrm{C} / \mathrm{N})$ ratio of the compost. The $\mathrm{C} / \mathrm{N}$ ratio is an important indicator in composting with $30: 1$ considered as an optimum value, and can be achieved by the addition of other materials.

The effective utilisation of FFB as organic amendment requires suitable treatments including composting to convert it into a more suitable material for soil application. Mohammad et al. (2012) reported that most of the EFB generated are returned to the oil palm plantations. Since compost is a better source of quality nutrients than the fresh material, in this context composting is an important part of valorising EFB. Chopping EFB, its composting and incorporation into the soil will enable quick release of nutrient to the soil (Budianta et al., 2010).

Bakar et al. (2011) stated that composting offers an alternative of using EFB as either fuel or mulch, but it brings additional operational costs and may require advance technology for higher efficiency and quality. Siddiquee et al. (2017) used two Trichoderma strains (strain SICCI and strain 11B) in composting EFB and demonstrated variations in the properties of the composts produced by the fungi and on their effects on soil properties. Compost from strain SICCI led to the highest $\mathrm{K}$ content of $6.7 \%$ after 8 weeks followed by that of strain $11 \mathrm{~B}(5.9$ $\%)$ and the control (soil without compost) had the lowest $\mathrm{K}$ content of $5.8 \%$. Trichoderma species increases composting rate, and function as a biological control agent (Shafawati and Siddiquee, 2013).

Vermicomposting is the use of different species of worms in composting operation to produce a nutrient rich material known as vermicompost suitable as soil amendment. Vermicompost is more fragmented and porous material, with less contaminants and high nutrient content (Rupani et al., 2010) compared to the raw material. An important advantage of vermicomposting technology over 
other technologies is the production of earthworm biomass, which is a good source of protein for animal feeds. Sabrina et al. (2009) reported that Eisenia fetida, Eisenia andrei, Lumbricus rubellus or Peryonix excavatus are mostly used in commercial vermicomposting. The earthworms prepare the biomass for microbial activities by fragmentation and conditioning, which leads to reduction in the $\mathrm{C} / \mathrm{N}$ ratio, and increased surface area (Singh et al., 2011).

Sabrina et al. (2009) demonstrated that EFB compost is toxic to Pontoscolex corethrurus, and Amynthas rodericensis, since only Eisenia fetida survived in EFB compost during vermincomposting operation using EFB with cow dung as supplement. Sabrina et al. (2009) reported that particle size affects the nutrient content of EFB vermicompost. The EFB of particle size more than $0.05 \mathrm{~m}$ led to significantly higher $(p<0.05) \mathrm{C} / \mathrm{N}$ ratio, $\mathrm{K}$, and $\mathrm{Mg}$ than fine particle size of less than $0.002 \mathrm{~m}$. The $\mathrm{pH}$ of the coarse EFB vermicompost was also significantly higher $(p<0.05)$ than the fine particles. However, the total nitrogen content of the EFB fine particles was significantly higher $(p<0.05)$ than the coarse particles (1.8, and $1.6 \%$, respectively). Nahrul Hayawin et al. (2010) investigated vermicomposting of EFB using African Nightcrawler (Eudrilus euginae) for 84 days, demonstrating increases in total $\mathrm{P}$ and $\mathrm{K}$ from $0.023 \%$ to $0.025 \%$, and $0.063 \%$ to $0.069 \%$ for raw EFB and EFB vermicompost, respectively. Similarly, total $\mathrm{Cu}, \mathrm{Zn}, \mathrm{Fe}$ and $\mathrm{Mn}$ in the final product $(\mathrm{Cu}-2.18, \mathrm{Zn}-2.82, \mathrm{Fe}-1.62$ and $\mathrm{Mn}-16.78 \mathrm{mg} / \mathrm{kg})$ were higher than in the original material $(\mathrm{Cu}-9.59, \mathrm{Zn}-$ 10.56, $\mathrm{Fe}-9.29$ and $\mathrm{Mn}-18.75 \mathrm{mg} / \mathrm{kg}$ ). 


\begin{tabular}{|c|c|c|c|c|}
\hline Analysis & PKS char & Reference & EFB char* & MF char ${ }^{* \star}$ \\
\hline \multicolumn{5}{|c|}{ Proximate (wt.\%) } \\
\hline Volatiles & $18-35$ & Abnisa et al. (2013); Nam et al. (2018) & $7.20-40.10$ & 52 \\
\hline Ash & $2-3$ & Abnisa et al. (2013); Nam et al. (2018) & $12.80-19.86$ & 4.30 \\
\hline Fixed carbon & $72.50-61$ & Abnisa et al. (2013); Nam et al. (2018) & $41.70-72.94$ & 30.60 \\
\hline \multicolumn{5}{|c|}{ Ultimate (wt.\%) } \\
\hline Carbon & $64-79.40$ & Abnisa et al. (2013); Nam et al. (2018) & $64.93-67.09$ & 67.70 \\
\hline Hydrogen & $3.18-5$ & Abnisa et al. (2013); Nam et al. (2018) & $2.02-2.55$ & 2.43 \\
\hline Nitrogen & $0.82-1$ & Abnisa et al. (2013); Nam et al. (2018) & $1.12-6.83$ & 0.65 \\
\hline Oxygen $^{\star * *}$ & $16.61-30$ & Abnisa et al. (2013); Nam et al. (2018) & $23.90-31.41$ & 29.23 \\
\hline $\mathrm{HHV}(\mathrm{kJ} / \mathrm{kg})$ & 28850 & Abnisa et al. (2013) & 21340 & 29.06 \\
\hline
\end{tabular}

${ }^{*}$ Abnisa et al. (2013) at $500{ }^{\circ} \mathrm{C}$ and Shariff et al. (2014) at $550{ }^{\circ} \mathrm{C},{ }^{* *}$ Abnisa et al. (2013), Nam et al. (2018) at 550 ${ }^{\circ} \mathrm{C}$, 
Table 5 shows the characteristics of vermicomposted EFB, non-vermicomposted (naturally composted) EFB, and non-composted (fresh) EFB treated with Gafsa rock phosphate (Sabrina et al., 2011). The nutrient contents of the EFB increased in the order of vermicompost>non-vermicompost $>$ fresh. This could be attributed to concentration of nutrients due to reduction in volume, the availability of nutrients due to breakdown of the EFB by the worms in the vermicomposting and composting processes. Razali et al. (2012) investigated the in-vessel composting of EFB, reporting improvement in the $\mathrm{C} / \mathrm{N}$ ratio from $77: 1$ to $13.8: 1$. Another important aspect of EFB valorisation is the separation into its component parts of EFS and BS. Zaharah and Lim (2000) reported that BS decomposed faster than EFS, which was because of relatively lower $\mathrm{C} / \mathrm{N}$ ratio of 73.2 and 96.2 and lignin of $28.1 \%$ and 29.1 $\%$, respectively.

Table 5 The characteristics of vermicomposted, non-vermicomposted (naturally composted), and non-composted (fresh) empty fruit bunch (EFB) treated with Gafsa rock phosphate (Source: Sabrina et al., 2011).

\begin{tabular}{llll}
\hline Parameter & \multicolumn{3}{c}{ Empty fruit bunch } \\
\cline { 2 - 4 } & Vermicompost & Composted & Fresh \\
\hline Organic C (\%) & 23.96 & 23.88 & 52.27 \\
Total N (\%) & 1.67 & 1.54 & 0.70 \\
pH 1:10 in water & 8.46 & 8.54 & 7.28 \\
Total P (\%) & 1.48 & 0.95 & 0.20 \\
Total K (\%) & 5.28 & 4.23 & 3.16 \\
Humic acid (g/g soil) & 0.08 & 0.04 & nd \\
\hline
\end{tabular}

nd - not detected

\subsubsection{Co-composting}

Addition of supplements to enhance the $\mathrm{C} / \mathrm{N}$ ratio in EFB composting is also called co-composting. Co-composting therefore is the use of more than one feedstock in composting. Decanter cake slurry can be collected separately from POME in palm oil mills. Yahya et al. (2010) reported that decanter cake slurry enhanced the formation of POME + EFB compost. Lower $\mathrm{C} / \mathrm{N}$ ratio of 18.65 against 28.96 from compost of 
323 no decanter cake slurry indicated mature compost. Nutongkaew et al. (2014) obtained 3.26 wt.\% N, 0.9 wt.\% P and 2.0 wt.\% $\mathrm{K}$ when POME was co-composted with EFB and decanter cake. Notably, POME, EFB, FFB solid wastes ash, and decanter cake slurry are oil mill wastes that can be co-composted, or anyone added to aid the composting process (especially ash and POME to EFB) with the potentials of increasing the value of the products as soil amendments. Lim et al. (2015) demonstrated the effects of Eudrilus eugeniae in vermicomposting of EFB supplemented with cow dung. The EFB vermicomposted without cow dung did not encourage the productivity of earthworms. This was because of high $\mathrm{C} / \mathrm{N}$ ratio. The EFB and cow dung of the ratio 2:1 showed the best quality vermicompost with higher increases in $\mathrm{Ca}(373 \%), \mathrm{P}(391 \%), \mathrm{K}(154 \%)$, and Mg (371\%), which was a demonstration of the lowest $\mathrm{C} / \mathrm{N}$ ratio it had. Rupani et al. (2013) investigated the effects of epigeic earthworms, Lumbricus rubellus on vermicomposting of MF treated with POME, cow dung, and lawn clipping for 50 days. There was significant decrease in the $\mathrm{C} / \mathrm{N}$ ratio due to the addition of lawn clipping, cow dung, and POME at the ratio of $15: 15: 50$, respectively compared to using only MF. Baharuddin et al. (2009) investigated the partial treatment of POME on EFB co-composting and reported reductions in the $\mathrm{C} / \mathrm{N}$ ratio. The initial $\mathrm{C} / \mathrm{N}$ values of $\mathrm{EFB}$ and POME were 56.5 and 13.5; the values were 15.7 after 45 days and 12.8 after 60 days. Similarly, Hock et al. (2009) investigated windrow co-composting of MF and POME anaerobic sludge and demonstrated reduction in the $\mathrm{C} / \mathrm{N}$ ratio from the values of 56.9 of raw MF and 8.3 for that of POME anaerobic sludge to the final matured compost of 12.6 after 50 days.

Thambirajah and Kuthubutheen (1989) compared treatments of MF composting, MF supplemented with poultry deep-litter and urea, and MF supplemented with poultry broiler floor-litter and urea. These authors found that the $\mathrm{C} / \mathrm{N}$ ratio reduced from 40 , 33 and 26 to 26,17 , and 16 , respectively after 8 weeks.

According to Yeoh et al. (2011) the higher porosity, water holding capacity, and nutrient holding capacity of EFB make it more suitable for composting compared to MF and PKS. There were limited reports on MF and PKS composting; however, the particulate nature of PKS makes it a potential bulking material for EFB, and MF composting. 


\section{Improving soil physical and chemical properties by the addition of fresh fruit bunch solid waste streams}

The PKS can be directly used as mulch without any form of treatment (Embrandiri et al., 2012). The dusty part of PKS with high MF is used locally in Nigeria as mulch in pineapple orchards (personal communication). Apart from moisture conservation, weed suppression, and erosion control effects, the decayed mulching materials increased soil nutrients (personal communication). When EFB is used in pyrolysis, the biochar can be further combusted or used as gasification feedstock or directly used on soil as amendment. The EFB is preferably used as mulch and as organic fertiliser to the soil (Lin, 2009; Moradi et al., 2012; Ohimain et al., 2013; Rosenani and Hoe, 1996; Sulaiman and Abdullah, 2011). These are true for MF and PKS except that most palm oil mills use MF and PKS preferably as fuels for the boilers to generate steam for heating and electricity. This is because it costs more energy to use EFB for energy compared to MF and PKS with lower moisture content and higher bulk densities. Similarly, until recently excess PKS has been deposited in the farms as a means of disposal in Nigeria. The EFB fibre and MF are used in erosion control, soil stabilisation, compaction reduction, landscaping and horticulture, as compost and organic fertiliser (Embrandiri et al., 2012 and Ohimain et al., 2013).

\subsection{Effects of empty fruit bunch on soil physico-chemical properties}

The EFB is being used as a source of soil nutrients for the nearby oil palm plantations (Yeoh et al., 2011), and as a result increases organic matter content of soil. The EFB is usually left to decompose on plantations and orchards helping to return organic matter to the soil, control weeds and erosion as well as retain moisture (Figure 3). Labour cost, high weight and volume to nutrient content ratio, and pest attraction are the limiting factors associated with the use of EFB as mulch and organic fertiliser (Sulaiman and Abdullah, 2011; Yusoff, 2006).

Sung et al. (2010) used Ecomat (mat or carpet compressed from EFB) and EFB as mulching materials and compared their effects on soil water content, demonstrating that the soil mulched with EFB had $27 \%$ more water than the soil mulched with 
Ecomat, and $38 \%$ more water than the control (without any mulch). The soil under Ecomat mulches had only $8 \%$ more water than bare soil. Sung et al. (2010) concluded that in terms of water conservation, one layer of EFB is equivalent to five layers of Ecomat. Carron et al. (2015) investigated the effects of decomposing EFB on soil properties at different time intervals. Expectedly, Carron et al. (2015) demonstrated that the soil total $\mathrm{N}, \mathrm{P}, \mathrm{K}, \mathrm{Mg}, \mathrm{Ca}$ and organic $\mathrm{C}$ of the decomposing EFB decreased with time with highest values recorded after 1 month, and the values were higher than the original EFB.

The EFB mulching affected the water retention curve by increasing significantly the amount of water held at field capacity (Moradi et al., 2015). The average daily soil water content was $0.2961 \mathrm{~m}$ due to EFB addition and was $0.2468 \mathrm{~m}$ due to pruned palm fronds addition. There was significant increase at depth of $0-0.15 \mathrm{~m}$ of the aggregate stability, available soil water content, and soil water concentration at field capacity using EFB and therefore significantly increased the relative proportion of soil mesopores $\left(2.0 \times 10^{-7}-3.0 \times 10^{-5} \mathrm{~m}\right)$ by $5 \%$ more than the silt pit. Additionally, EFB led to the highest amount of organic matter into the soil than pruned palm frond, Ecomat, and silt pit (Moradi et al., 2015). The high organic matter led to the changes in available water content of $13,10,10,9 \% \mathrm{v} / \mathrm{v}$ due to EFB, pruned palm frond, Ecomat, and silt pit, respectively.

Rosenani and Hoe (1996) investigated the decomposition of single and double layered EFB and have shown that $71 \%$ of double layered EFB decayed within 15 weeks while $68 \%$ of single layered EFB decayed within the same period. This was attributed to high microbial activity within the double layered. Similarly, the single layered EFB increased the soil total nitrogen from $0.23 \%$ to $0.27 \%$ while the doubled layered increased to $0.28 \%$.

When compared to chemical fertiliser, EFB application at the rate of 0.3 tonne/palm/yr significantly increased $(P=0.01)$ the soil $\mathrm{pH}$ by 2 , and cation exchangeable capacity by $5.5 \mathrm{cmol}(+) / \mathrm{kg}$ more than chemical fertilizer in the $0.2-$ $0.4 \mathrm{~m}$ soil layer (Bakar et al., 2011). Budianta et al. (2010) demonstrated that the application of EFB at the rate of $40 \mathrm{Mg} / \mathrm{ha} / \mathrm{yr}$ for 3 years $(\mathrm{pH}=5.85)$ resulted in a significant difference $(\mathrm{p}<0.05)$ in $\mathrm{pH}$ at soil depth of $0-0.2 \mathrm{~m}$ against the control $(\mathrm{pH}$ 
$416=4.74)$. The soil $\mathrm{pH}$, exchangeable $\mathrm{K}, \mathrm{Mg}$ and $\mathrm{Ca}$, organic $\mathrm{C}$, and total $\mathrm{N}$ were 0.8 , $4170.3 \mathrm{cmol}(+) / \mathrm{kg}, 3.2 \mathrm{cmol}(+) / \mathrm{kg}, 9.2 \mathrm{cmol}(+) / \mathrm{kg}, 1.2 \%$, and $0.2 \%$ more than the control due to application of EFB at the rate of 37.5 tonnes/ha/yr, respectively (Chiew and Rahman, 2002). There was significant effect due to EFB application on soil organic $\mathrm{C}$, with $38.1 \%$ higher than that using silt pit and pruned oil palm fronds, and $36.4 \%$ higher than Ecomat at depth of $0-0.15 \mathrm{~m}$, and exchangeable $\mathrm{Mg}$ and $\mathrm{Ca}$ (Moradi et al., 2012). Moradi et al. (2012) also reported an increase in soil exchangeable $\mathrm{K}$ up to $70 \%$ higher than silt pit, pruned oil palm fronds and Ecomat. Budianta et al. (2010) demonstrated that the application of EFB at the rate of 40 $\mathrm{Mg} / \mathrm{ha} / \mathrm{yr}$ for 2 years increased significantly exchangeable $\mathrm{Mg}$ by $100 \%$ compared to the control (without EFB application). There was no significant effect on soil organic $\mathrm{C}$, and cation exchangeable capacity, $\mathrm{N}$ and $\mathrm{P}$ at $0-0.2 \mathrm{~m}$ depth after a year using $40 \mathrm{Mg} / \mathrm{ha} / \mathrm{yr}$ of EFB (Budianta et al., 2010).

The PKS is used locally in Nigeria as a cooking fuel, on local roads or open premises of residential houses and in oil mill plantations. When used on roads and premises of residential houses, PKS presents a cost-effective means of soil erosion prevention. There were limited reports on the use of MF and PKS to improve soil physicochemical properties, however Hock et al. (2009) report that co-composting using excess MF (not used for energy purposes) and POME led to a material of higher nutrients content suitable for soil use.

\subsection{Effects of ash and biochar from fresh fruit bunch wastes on soil physico-chemical properties}

Soil nutrient is very essential in plant growth and metabolism. Crop growth and yield depends on equilibrium between nutrient supply from either amendments or soil metabolism, and demand by crops. Local farmers in Nigeria use ash from the combustion of FFB solid wastes as a replacement for lime. Ash can improve soil nutrient quality, act as lime replacement, and stimulate microbial activities (Awodun et al., 2007). Conversely, Ojeniyi et al. (2010) demonstrated an increase in soil organic matter by 0.16 and $0.06 \%$ more than the control due to the addition of EFB ash on a field experiment at Benin and Ekiadolor in southern Nigeria, respectively. Awodun et al. (2007) reported significant increases in soil organic matter up to $51 \%$, 
due to application of EFB ash at levels of $0,2,4,6$, and 8 tonnes/ha. The ash from the combustion of MF and PKS is returned to plantations as soil amendment (Elbersen et al., 2013), which is a positive development.

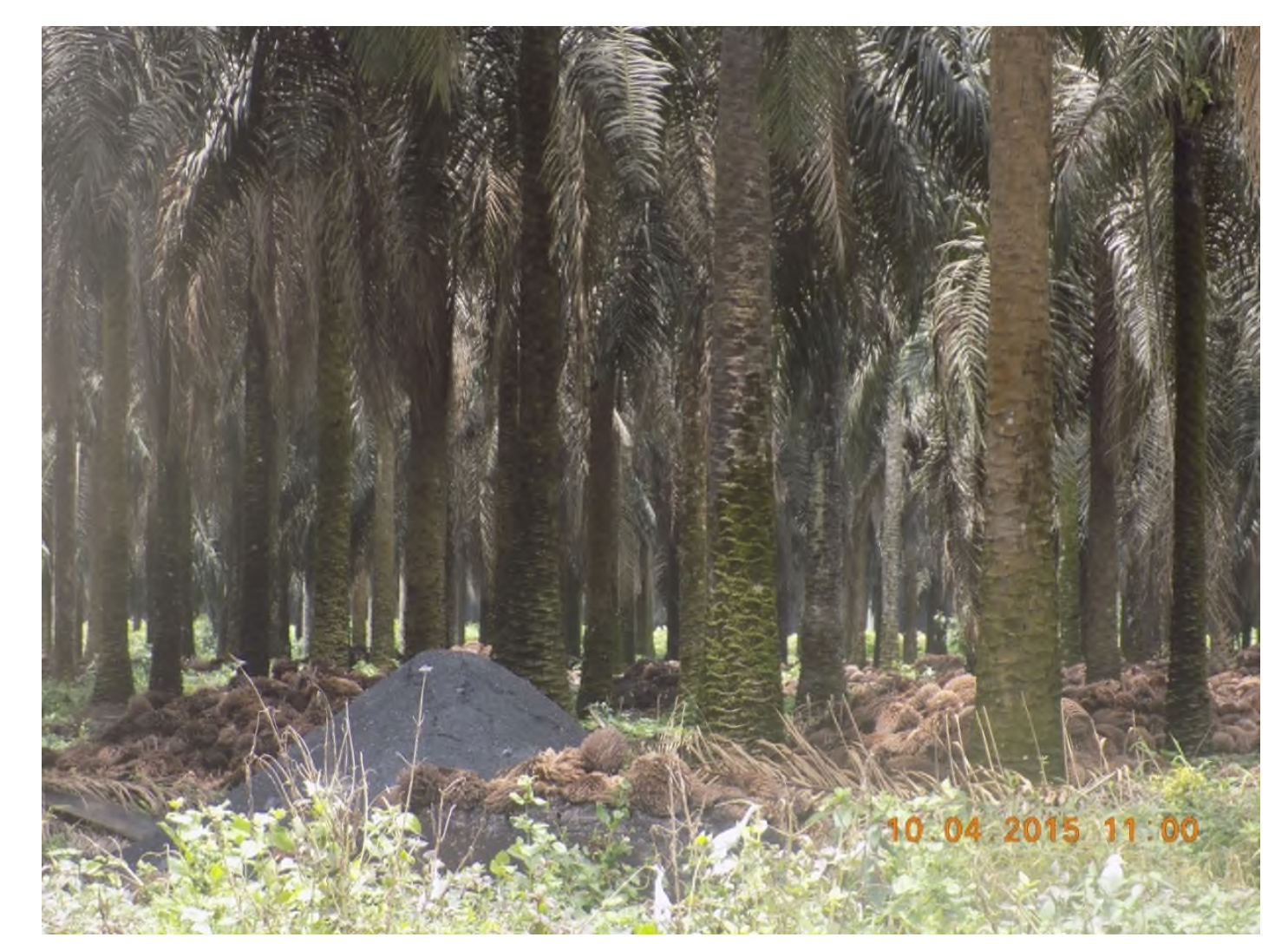

Figure 1 Empty fruit bunch and ash dumped into an oil palm plantation. This is the poor practice in Nigeria due to enormous amount of the wastes generated with no other form of disposal.

The high nutrient content in EFB ash increases its positive effects on soil fertility (Table 6). Awodun et al. (2007) reported an increase in soil N (48\%), P (51\%), K (61\%), $\mathrm{Ca}(43 \%), \mathrm{Mg}(68 \%)$ due to application of EFB ash with the levels of $0,2,4$, 6 and 8 tonnes/ha. Some literature reports on properties of EFB ash are shown in Table 6. Ojeniyi et al. (2010) investigated the effects of 4 tonnes/ha EFB ash, and 0.3 tonne/ha nitrogen-phosphorus-potassium (NPK) (15-15-15) fertiliser, and their mixture at different levels, and demonstrated that EFB ash at 4 tonnes/ha recorded the highest $\mathrm{K}$ and $\mathrm{pH}$ values in the soil. Similarly, Awodun et al. (2007) reported an increase in soil organic matter due to application of EFB ash as the application level 


\begin{tabular}{|c|c|c|}
\hline Parameter & Empty fruit bunch ash & References \\
\hline $\mathrm{pH}\left(\mathrm{H}_{2} \mathrm{O}\right)$ & $7.50-10.89$ & $\begin{array}{l}\text { Adjei-Nsiah and Obeng (2013); Akanbi et al. } \\
\text { (2014) }\end{array}$ \\
\hline \multirow[t]{2}{*}{ Organic C } & $0.55-1.92 \%$ & $\begin{array}{l}\text { Adjei-Nsiah and Obeng (2013) Gbaraneh and } \\
\text { Chu (2016) }\end{array}$ \\
\hline & $0.17 \%$ & Akanbi et al. (2014) \\
\hline \multirow[t]{2}{*}{ Total $\mathbf{N}$} & $0.08-0.19 \%$ & $\begin{array}{l}\text { Adjei-Nsiah and Obeng (2013); Gbaraneh } \\
\text { and Chu (2016); Ojeniyi et al. (2009) }\end{array}$ \\
\hline & $0.02 \%$ & Akanbi et al. (2014) \\
\hline Total P & $0.26-0.18 \%$ & Gbaraneh and Chu (2016) \\
\hline \multirow[t]{2}{*}{ Total $\mathrm{K}$} & $27.10-28.30 \%$ & Gbaraneh and Chu (2016) \\
\hline & $2.65 \%$ & Akanbi et al. (2014) \\
\hline Total Ca & $6.59-8.10 \%$ & Gbaraneh and Chu (2016) \\
\hline Total Mg & $3.10-3.33 \%$ & Gbaraneh and Chu (2016) \\
\hline $\mathrm{C} / \mathrm{N}$ ratio & $10.10-10.9$ & Gbaraneh and Chu (2016) \\
\hline Exchangeable $\mathrm{K}$ & $582.77 \mathrm{cmol} / \mathrm{kg}$ & Adjei-Nsiah and Obeng (2013) \\
\hline Exchangeable $\mathrm{Ca}$ & $0.85-34.93 \mathrm{cmol} / \mathrm{kg}$ & $\begin{array}{l}\text { Adjei-Nsiah and Obeng (2013); Akanbi et al. } \\
\text { (2014); Ojeniyi et al. (2009) }\end{array}$ \\
\hline Exchangeable Mg & $1.80-29.08 \mathrm{cmol} / \mathrm{kg}$ & $\begin{array}{l}\text { Adjei-Nsiah and Obeng (2013); Akanbi et al. } \\
\text { (2014); Ojeniyi et al. (2009) }\end{array}$ \\
\hline \multirow[t]{2}{*}{ Available P } & $0.19 \%$ & Ojeniyi et al. (2009) \\
\hline & $0.02 \%$ & Akanbi et al. (2014) \\
\hline
\end{tabular}

increased from 0, 2, 4, 6 and 8 tonnes/ha. The 8 tonnes/ha EFB ash level recorded the highest organic matter content of $3.4 \%$ while the control led to the lowest value of $1.8 \%$ in Nigeria. Similar result was obtained for the soil exchangeable $\mathrm{K}$ with the 8 tonnes/ha ash level, which was $0.37 \mathrm{cmol} / \mathrm{kg}$ more than the control. Adjei-Nsiah and Obeng (2013) demonstrated that significantly $(p<0.05)$ more soil $\mathrm{pH}(0.7)$, available $\mathrm{P}(6.29 \mathrm{ppm})$ and exchangeable $\mathrm{K}(0.34 \mathrm{cmol} / \mathrm{kg}), \mathrm{Ca}(0.76 \mathrm{cmol} / \mathrm{kg})$ and $\mathrm{Mg}(1.06$ $\mathrm{cmol} / \mathrm{kg}$ ) than the control due to the application of 4 tonnes $/ \mathrm{ha}$ EFB ash.

Table 6 Characteristics of empty fruit bunch (EFB) ash from literature. 
Biochar can help to mitigate climate change through stable carbon storage and the reduction of GHG emissions when added to the soil (Kong et al., 2014). Abdulrazzaq et al. (2015) investigated the use of EFB biochar on soil properties and concluded that EFB biochar is more suitable for soil fertility improvement compared to rice husk biochar. There was a significant difference in the hydraulic conductivity, mean porosity and drained upper limit of soil due to the EFB biochar compared with the control (soil without any biochar). The hydraulic conductivity, mean porosity, and drained upper limit of soil of the 30 tonnes/ha EFB biochar treatment were 0.75 $\mathrm{cm} / \mathrm{h}, 5 \%$, and $0.07 \%$ more than the control. The micropore area and pore volume of the biochar led to improvement in the soil porosity. High drained upper limit enhances the soil aeration potential. Bakar et al. (2015) reported that the soil available $\mathrm{P}$, and exchangeable $\mathrm{Ca}$ increased by 41 , and $37 \%$ more than the control, respectively using 40 tonnes/ha EFB biochar in a pot study on the effects of EFB biochar on the growth performance of rice. Lee et al. (2017b) reported that the application of $20 \mathrm{Mg} / \mathrm{ha}$ EFB biochar increased soil exchangeable $\mathrm{Ca}, \mathrm{K}$ and $\mathrm{Mg}$, and cation exchange capacity significantly by $45.45,343.4$ and 72.73 , and $3.14 \%$ more than the control (no biochar), respectively. Conversely, the soil exchangeable Al significantly decreased by $34.17 \%$.

\section{Crop response to fresh fruit bunch waste streams}

The availability of soil nutrients is the major factors affecting crop yield including oil palm. Land slope under intensive rainfall conditions limits crop productivity due to increased loss of nutrient from soil erosion (Moradi et al., 2012). Therefore, mulching has proven to be an effective method of controlling erosion and increasing crop growth and yield. Laying EFB on top of the soil has been an effective means of utilising the waste for crop growth. The oil palm leaf $P$ was 0.08 and $0.07 \%$ more compared to the control (oil palm fronds) and silt pit after 6 months of application of EFB at the rate of 1 tonne/treatment plot/yr, respectively. Comparing EFB and oil palm fronds, EFB decomposed at a faster rate than oil palm fronds and therefore released significantly higher amounts of $\mathrm{K}$ and $\mathrm{Ca}$ after 6 months (Moradi et al., 2012). The decomposition rate influences nutrient release and hence crop yield. There was an increase in oil palm FFB yield (21, 30 and 34 tonnes/ha/yr), bunch number (990, 1197, and 1256) and average bunch weight yield (21, 25 and $27 \mathrm{~kg}$ ) 
due to the control, and the application of 37.5 and 75 tonnes/ha/yr EFB mulch, respectively (Chiew and Rahman, 2002). Similarly, the $N$ content of the oil palm leaf increased significantly to 2.7 and $2.9 \%$, respectively while the control was $2.6 \%$. Ravoof (1988) demonstrated that EFB single layer mulch can be used to grow sweet potato on a sandy soil without fertiliser. Bakar et al. (2011) compared the effects of chemical fertiliser, and EFB at rates of 0.15 and 0.3 tonne/palm/yr as mulch in oil palm plantation for 10 years and concluded that there was no significant difference between the application of EFB at the rate of 0.15 tonne/palm/yr and chemical fertilizer, however the 0.3 tonne/palm/yr rate was $9 \%$ higher. Similarly, EFB at the rate of 0.15 tonne/palm/yr increased significantly $(p=0.01)$ soil organic $C$ in the top soil. According to Sridhar and AdeOluwa (2009), adding EFB at 6 tonnes/ha can return half the nutrients originally harvested in the FFB on decomposition.

Asiah et al. (2004) demonstrated that EFB could be used as growing medium for hybrid cauliflower plant although, when compared to coconut coir dust resulted in lower total dry matter yield $(0.006 \mathrm{~g} /$ plant) and total nitrogen uptake (more than 300 mg N/plant) 42 days after transplanting. Tabi et al. (2008) demonstrated that $100 \%$ EFB as substrate for the cultivation of pleurotus ostreatus (mushroom) could not produce pleurotus ostreatus fruit bodies, whereas $100 \%$ MF produced $4.6 \%$ biological efficiency (the yield of fresh fruit bodies per $100 \mathrm{~g}$ dry substrate. The $50 \%$ MF and $50 \%$ rubber tree sawdust produced the highest biological efficiency of 11.3 $\%$, which is the same value produced by $100 \%$ rubber tree sawdust used commercially as substrate for pleurotus ostreatus cultivation (Tabi et al. 2008). The low content of nitrogen in EFB was responsible for the inability of the mycelium to grow. The MF can be used to grow pleurotus ostreatus or in combination with rubber tree sawdust. Hoe (2014) used MF as a growing media for banana tissue culture seedlings and demonstrated that the height of the banana seedling increased significantly (Tukey's HSD $5 \%$ ) by $0.0746,0.1292$, and $0.1824 \mathrm{~m}$ due to the use of MF more than the control (only soil) after weeks 5, 6 and 7, respectively.

There were limited reports on the application of raw PKS on soil for crop improvement, however as stated above the dusty part of PKS with high MF is used locally in Nigeria as mulch in pineapple orchards (personal communication). The effects on pineapple growth and yield have not been documented. 


\subsection{Crop response to empty fruit bunch compost}

Haya et al. (2017) demonstrated that the K content of orange-fleshed sweet potato storage root increased significantly $(p<0.05)$ due to the application of EFB compost + $30 \mathrm{ppm}$ hexaconazole (growth regulator) by $107 \%$ more than the control. The EFB compost led to a significant increase $(p<0.05)$ in the $K$ contents of the sweet potato leaf, stem and root by $0.58,0.68$, and $0.37 \%$ more than the control, respectively. These were due to the EFB compost providing the soil the ability to retain $\mathrm{K}$ long enough for the plant to absorb it compared to the control (inorganic fertiliser). However, the use of $100 \%$ EFB compost was found to be responsible to stunted growth in okra (Siddiqui et al. 2009), and a decrease in germination of okra seeds as EFB compost level increased against chicken manure. The EFB compost level of 25, 50,75 and $100 \%$ resulted in $81.4,49.72,48.14$ and $9.9 \%$ germination, respectively.

\subsection{Crop response to empty fruit bunch ash}

Awodun et al. (2007) reported an increase in maize leaf $\mathrm{Ca}$ of up to $13 \%$ due to 6 and 8 tonnes/ha of EFB ash, which was higher than the control when EFB ash (levels of $0,2,4,6$ and 8 tonnes/ha) was applied at two different sites. Awodun et al. (2007) also reported significant increase in maize cob and grain yield except at 8 tonnes/ha ash level with the highest yield of $0.053 \mathrm{~kg} /$ plant of maize cob and 0.046 $\mathrm{kg} / \mathrm{plant}$ of maize grain obtained at 6 tonnes/ha.

Akanbi et al. (2014) investigated the effects of 1, 2, 3, 4 and 5 tonnes/ha levels of EFB and cocoa pod husk ash, respectively and $10 \mathrm{~kg}$ of the NPK (20:10:10) fertiliser on the growth and dry matter yield of cocoa (Theobroma cacao). These authors demonstrated that EFB ash at the level of 4 tonnes/ha significantly $(p<0.05)$ increased the height and root length of cocoa seedlings more than the NPK (20:10:10) fertiliser by 0.0476 and $0.2 \mathrm{~m}$, respectively. Ojeniyi et al. (2009) investigated the effects of $1.25,2.50,3.75$ and 5.00 tonnes/ha EFB ash, and 0.6 tonne/ha NPK (15:15:15) fertiliser against no amendment application on cassava performance. The 2.5 tonnes/ha EFB ash led to significantly higher $(p<0.05)$ sweet cassava tuber yield, which exceeded the NPK (15:15:15) fertiliser by $83 \%$. Gbaraneh and Chu (2016) compared the effects of 10 tonnes/ha EFB ash, 10 tonnes/ha poultry manure, 0.2 tonne/ha NPK (20:10:10) fertiliser and the mixtures of 
the amendments on soil nutrient status and performance of okra. All the treatments increased okra pod length, weight and total yield against the control, the 10 tonnes/ha EFB ash level was only greater than the control by $5 \mathrm{~mm}, 0.0053 \mathrm{~kg}$, and 1.96 tonnes/ha, respectively in the second year. The 5 tonnes/ha EFB ash +0.1 tonne/ha NPK increased the okra pod length, weight and total yield more than the 10 tonnes/ha EFB ash level. This is in line with Siddiqui et al. (2009) report on okra performance using EFB compost as stated above. Adjei-Nsiah and Obeng (2013) demonstrated significant increase $(\mathrm{p}<0.05)$ in the mean leaf $\mathrm{P}$ and $\mathrm{K}$ of eggplants, okra, and pepper of $0.1,0.1$ and $0.08 \%$ and $0.09,0.1,0.08 \%$ more than the control due to the application of 2, 4 and 6 tonnes/ha EFB ash levels, respectively.

Recent reports on the use of ash from FFB solid wastes focused on EFB ash; however, MF and PKS are mostly used in palm oil mill combustors (boilers), with the generation of ash as residue. Reports above have shown that EFB ash is important to crop yield and therefore there is a need to consider the use of EFB together with MF and PKS in boilers to increase the quality of the ash produced for soil properties and crop improvement.

\subsection{Crop response to fresh fruit solid wastes biochar}

Nam et al. (2018) investigated the use of PKS biochar at three levels of $10 \mathrm{~g}, 20 \mathrm{~g}$ and $30 \mathrm{~g}$ for the cultivation of mushroom (Pleurotus ostreatus) by adding rice bran and sawdust as sources of nutrient while $\mathrm{Ca}$ carbonate was used to balance the $\mathrm{pH}$. The $20 \mathrm{~g}$ level led to the highest yield of $500 \mathrm{~g}$ mushroom, which was $50 \%$ more than the control. The biochar retained more nutrient and water for the growth of the mushroom compare with the treatment without biochar. Similarly, the mean shoot dry weight of the sweet corn was $220 \mathrm{~g}$ per plot due to the EFB biochar application, while that of the control (without biochar) was $50 \mathrm{~g}$ per plot (Abdulrazzaq et al., 2015). Bakar et al. (2015) reported that the maximum height of rice, number of panicles/hill, weight of 1000 grains, and total biomass/hill were 22.20, 163, 52.53, and $318.60 \%$ more than the control, respectively using 40 tonnes/ha EFB biochar in a pot study on the effects of EFB biochar on the growth performance of rice. Additionally, the $\mathrm{P}, \mathrm{K} \mathrm{Ca}$, and $\mathrm{Mg}$ concentrations in the rice plant significantly increase by $221.14,601.27,336.55$, and $293.60 \%$ more than the control, 
respectively due to the 40 tonnes/ha EFB biochar application. The application of 10 $\mathrm{Mg} / \mathrm{ha}$ EFB biochar resulted in $77.4 \%$ significant increase in the total dry matter weight of maize compared to the control (Lee et al., 2017b). Similarly, the K, P, and Mg uptake by the maize aboveground biomass increased significantly by 246, 97, and $83.9 \%$ more than the control, respectively due to the application of $20 \mathrm{Mg} / \mathrm{ha}$ EFB biochar.

\section{Prospects and challenges}

The incineration of EFB leads to emission of particulates including tar and soot droplets (Tabi et al., 2008) and the wastage of heat. The dumping of EFB takes up large space (Mohammad et al., 2012). The earlier means of disposing EFB, PKS, MF, and the ash was dumping in the farms or roadside especially in Nigeria. Over the years, these wastes have attracted interest due to the impacts on soil properties, soil nutrient availability, crop yield, and soil erosion. Tabi et al. (2008) concluded that a new usage of the FFB solid wastes should be looked into to minimise any pollution. It has been reported above that PKS is used as fuel, Haryati et al. (2016) stated that the left over PKS when disposed add pressure to the land.

The combustion or gasification of the FFB solid wastes increases fouling and corrosion of the thermal facilities due to the high content of alkali metals in the biomass, which reduces the heat transfer capacity of the heat exchangers. The low melting point of these metals leads to slagging, which increases cost of maintenance. Haryati et al. (2016) reported that the lower nitrogen content of PKS biochar relative to the feedstock is an added advantage in terms of low level of fuel NOx during combustion. When EFB is burnt, it generates undesirable air pollution. When it is returned to the plantations, it takes weeks before the heaps are turned leading to poor decomposition and emission of methane. According to Elbersen et al. (2013), poor decomposition of EFB contributes to greenhouse gas emissions by the release of methane and nitrogen oxide up to 0.23 tonne carbon dioxide equivalent per tonne of EFB, which can be reduced to 0.05 tonne carbon dioxide equivalent/tonne of EFB by a well-controlled compositing facility. Krishnan et al. (2016) supported Elbersen et al. (2013) by demonstrating that the EFB and POME co-composting can reduce greenhouse gas emissions by $76 \%$. This was achieved 
by avoiding open dumping of EFB and pond treatment of POME. The capture and burning of the released biogas from the decomposition of EFB in a flare would reduce the greenhouse gas emissions by $95 \%$ (Elbersen et al., 2013). Sabrina et al. (2012) demonstrated that extractible phenols from field decomposed EFB decreased with increasing age of the EFB compost. Similar types of phenols were found in fresh field decomposed and composted EFB, which had no harmful effect on earthworm population. Sabrina et al. (2012) concluded that vermicomposting could degrade toxic compounds as no phenols were found in vermicomposted EFB.

The processing of the EFB to enhance its value will generate employment and therefore reduce social unrest in areas where unemployment is a major challenge. This is true with the production of Ecomat from EFB, which is used as a landscaping and mulching material in urban area (Sung et al., 2010). Elbersen et al. (2013) reported that the value of EFB returned to the field was estimated to be up to $\$ 3.3$ per tonne due to the benefit from replacing fertiliser, the costs for transport and spreading. However, the economic benefit of using EFB as a fuel for power generation is 3.5 times the benefit of using EFB as a mulch (Elbersen et al., 2013). Harsono et al. (2013) reported that the cost of transporting raw EFB to the palm oil plantation is $81 \%$ more than the cost of transporting the EFB biochar, leading to a savings of $21,384 \mathrm{US} \$ / \mathrm{yr}$. Bakar et al. (2011) reported that 0.15 tonne/palm/yr of EFB could replace chemical fertiliser in terms of FFB yield.

\subsection{Environmental risk of ash application}

The challenges of poor ash management affect humans, animals, soil and plants as well as occupy valuable space. Most palm oil mills dispose the ash from combustion of MF and PKS by returning it to the plantation or landfills (Alsubari et al., 2018) the same way the EFB is disposed. The ash from MF and PKS are used on roads leading to palm oil mills (Vijaya et al., 2008). The environmental implication of this form of disposal has not been fully documented. The combustion of EFB for ash generation has been reported, although the practice has been prohibited in Malaysia (Elbersen et al., 2013; Moradi et al., 2014).

Few of the countries in Europe with regulations/recommendations on the use of ash for agricultural purposes are Austria, United Kingdom, Germany, Denmark, Sweden, 
and Finland. The considerations for the regulations include heavy metals and organic compounds content and application per year per hectare. Only ash from clean biomass fuels is allowed for agriculture or forestry applications in Sweden (Van Eijk et al., 2012) and for sustenance purposes only (Hanman et al., 2016). In Austria, $2 \%$ weight base is the maximum biomass ash allowed in composting (Van Eijk et al., 2012). In Finland ash application is allowed for restoration purposes only and not to increase tree growth whereas in Denmark, Finland, Lithuania, Sweden and the United Kingdom ash application is recommended to prevent negative impacts due to the harvesting of forest biomass (Hanman et al., 2016).

\subsection{Outlook for fresh fruit bunch solid wastes valorisation}

The best value from FFB wastes is achievable if a proper waste management system is part of the design of the palm oil mills, or a separate facility designed to match the capacity of the palm oil mills. Figure 4 is a flow chart describing the different routes to the utilisation of FFB solid waste streams as soil ameliorants, which can be considered in designing palm oil mills. The EFB, MF and PKS, and their by-products in different forms can add nutrients to the soil, used as mulching materials, in erosion control, soil liming, and in carbon sequestration. The biochar generated from pyrolysis can be used in either combustion or gasification, which is potentially effective in reducing environmental challenges of thermal conversion of the raw biomass. Similarly, the ash produced can be used to aid composting. As suggested by the model, the wastes can be used simultaneously or separately. The simultaneous utilisation may provide opportunity for improvements and reduce the needless disposal of any of the wastes. 


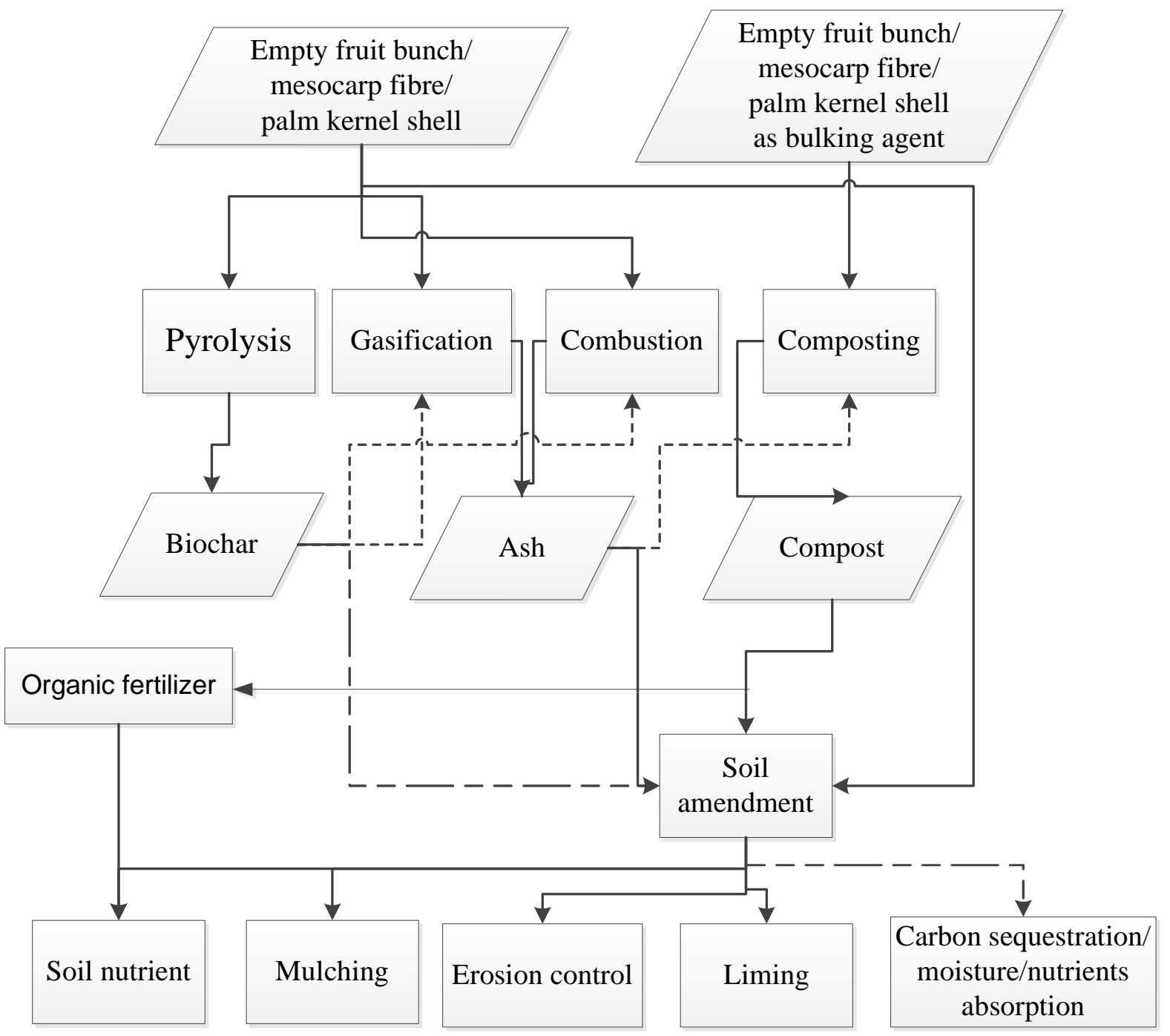

Figure 1 Flow chart for fresh fruit bunch solid wastes valorisation as soil ameliorant.

\section{Conclusions}

The EFB, MF, and PKS are used as boiler fuels and the generated ash used as soil amendments. The challenges of FFB solid wastes use as fuel for the generation of ash and biochar include low bulk density, high moisture content, and high alkali content. Low bulk density limits the transportation of the raw biomass especially EFB and their residue to areas in high demand. It forces the palm oil mills to deposit the wastes including ash within the palm oil mills, adding pressure to the limited land 
means of increasing the value of the wastes, which also leads to valuable soil ameliorants. The processes include pyrolysis (biochar), gasification (ash), combustion (ash), and composting (compost). There is a need to include in the design of palm oil mills other facilities to manage the wastes especially EFB. A wellbalanced utilisation of the FFB solid wastes will reduce the negative impacts of disposal of the wastes, including greenhouse gas emissions, pest breeding, pressure on land resources, and the waste of potential soil ameliorants and the attendant economic losses. Co-utilisation (pyrolysis, gasification, combustion, and composting) of the EFB, MF and PKS a suitable option in effective management of the wastes.

\section{Acknowledgements}

This is part of research project under the funding of Tertiary Education Trust Fund (TETFUND), Nigeria and support of Imo State Polytechnic Umuagwo, Ohaji Imo State, Nigeria.

\section{References}

Abdullah, N., Sulaiman, F., 2013. The properties of the washed empty fruit bunches of oil palm. Journal of Physical Science, 24(2), 117-137.

Abdulrazzaq, H., Jol, H., Husni, A., Abu-Bakr, R. 2015. Biochar from Empty Fruit Bunches, Wood, and Rice Husks: Effects on Soil Physical Properties and Growth of Sweet Corn on Acidic Soil. Journal of Agricultural Science, 7(1), 192200.

Abnisa, F., Arami-Niya, A., Daud, W.W., Sahu, J.N., 2013. Characterization of bio-oil and bio-char from pyrolysis of palm oil wastes. BioEnergy Research, 6(2), pp.830-840.

Adjei-Nsiah, S., Obeng, C.B., 2013. Effect of Palm Bunch Ash Application on Soil and Plant Nutrient Composition and Growth and Yield of Garden Eggs, Pepper and Okra. International Journal of Plant and Soil Science, 2(1), 1-15.

Akanbi, O.S.O., Famaye, A.O., Olaniyi, O.O., Ipinmoroti, R.R., Iloyanomo, C.I., Nduka, B.A., Adeosun, S.A., 2014. Comparative Effects of Cocoa Pod Husk and 
Oil Palm Bunch Ash on Nutrient Uptake, Growth and Dry Matter Yield of Cocoa (Theobroma cacao) in Ibadan, Southwest Nigeria. Agricultural Sciences, 5, 1046-1052.

Alsubari, B., Shafigh, P., Ibrahim, Z., Alnahhal, M.F., Jumaat, M.Z., 2018. Properties of eco-friendly self-compacting concrete containing modified treated palm oil fuel ash. Construction and Building Materials, 158, 742-754.

Anyaoha, K.E., Sakrabani, R., Patchigolla, K., Mouazen, A.M. 2018. Evaluating oil palm fresh fruit bunch processing in Nigeria. Waste Management \& Research, $O(0), 1-11$.

Arzola, N., Gómez, A., Rincón, S., 2012. The effects of moisture content, particle size and binding agent content on oil palm shell pellet quality parameters. INGENIERIA INVESTIGATION, 32(1), 24-29.

Asadullah, M., Adi, A.M., Suhada, N., Malek, N.H., Saringat, M.I., Azdarpour, A., 2014. Optimization of palm kernel shell torrefaction to produce energy densified bio-coal. Energy Conversion and Management, 88, 1086-1093.

Asiah, A., Mohd Razi, I., Mohd Khanif, Y., Maziah, M. and Shaharuddin, M., 2004. Physical and Chemical Properties of Coconut Coir Dust and Oil Palm Empty Fruit Bunch and the Growth of Hybrid Heat Tolerant Cauliflower Plant. Pertanika Journal of Tropical Agricultural Science, 27(2), 121-133.

Awodun, M.A., Adeboye, A., Odedina, S.A., 2007. Effect of Oil palm Bunch Refuse Ash on Soil and Plant Nutrient Composition and Yield of Maize. AmericanEurasian Journal of Sustainable Agriculture, 1(1), 50-54.

Baharuddin, A.S., Kazunori, N., Abd-Aziz, S., Tabatabaei, M., Abdul Rahman, N.A., Hassan, M.A., Wakisaka, M., Sakai, K. and Shirai, Y. 2009. Characteristics and Microbial Succession in Co-Composting of Oil Palm Empty Fruit Bunch and Partially Treated Palm Oil Mill Effluent. The Open Biotechnology Journal, 3, pp.87-95.

Bakar, R.A., Darus, S.Z., Kulaseharan, S., Jamaluddin, N., 2011. Effects of ten year application of empty fruit bunches in an oil palm plantation on soil chemical 
properties. Nutrient Cycling in Agroecosystems, 89, 341-349.

Bakar, R. A., Razak, Z. A., Ahmad, S. H., Seh-Bardan, B. J., Tsong, L. C., Meng, C. P. 2015. Influence of oil palm empty fruit bunch biochar on floodwater $\mathrm{pH}$ and yield components of rice cultivated on acid sulphate soil under rice intensification practices. Plant Production Science, 18(4), 491-500.

Bazargan, A., Rough, S.L., Mckay, G., 2014. Compaction of palm kernel shell biochars for application as solid fuel. Biomass and Bioenergy, 70, 489-497.

British Standards Institute BS EN 15403: 2011: Solid recovered fuels Determination of ash content. https://bsol.bsigroup.com/ (accessed 12 March 2015).

Budianta, D., Yasmin, A., Wiralaga, A., Lestari, W., 2010. Changes in Some Soil Chemical Properties of Ultisol Applied by Mulch from Empty Fruit Bunches in an Oil Palm Plantation. J Trop Soils, 15(2), 111-118.

Carron, M.P., Pierrat, M., Snoeck, D., Villenave, C., Ribeyre, F., Suhardi, Caliman, J. P., 2015. Temporal variability in soil quality after organic residue application in mature oil palm plantations. Soil Research, A-K.

Chiew, L.K., Rahman, Z.A., 2002. The Effects of Oil Palm Empty Fruit Bunches on Oil Palm Nutrition and Yield, and Soil Chemical Properties. Journal of Oil Palm Research, 14(2), 1-9.

Claoston, N., Samsuri, A.W. , Ahmad Husni, M.H., Mohd Amran, M.S., 2014. Effects of pyrolysis temperature on the physicochemical properties of empty fruit bunch and rice husk biochars. Waste Management \& Research, 32(4), 331-339.

Elbersen, H.W., Meesters, K.P.H., Bakker, R.R.C., 2013. Valorization of palm oil (mill) residues. Identifying and solving the challenges Wageningen. http://library.wur.nl/WebQuery/wurpubs/448069 (accessed 7 November 2016).

Embrandiri, A., Singh, R.P., Ibrahim, H. M., Ramli, A.A., 2012. Land application of biomass residue generated from palm oil processing: its potential benefits and threats. The Environmentalist, 32, 111-117. http://doi.org/10.1007/s10669-0119367-0. 
Gbaraneh, L.D., Chu, G.C.S., 2016. Effects of palm bunch ash, poultry manure and NPK fertiliser and their combinations on soil productivity and yield of Okra (Abelmoschus esculentsus) in South-south Nigeria. International Journal of Scientific Research and Education, 4(8), 5674-5684.

Hanman, K.D., Deschamps, C., Kwiaton, M., Venier, L., Hazlett, P.W., 2016. Regulations and Guidelines for use of wood ash as soil amendment in Canadian forests. Information report GLC-X-17.

Harimi, M., Megatahmad, M., Sapuan, S., Idris, A., 2005. Numerical analysis of emission component from incineration of palm oil wastes. Biomass and Bioenergy, 28, 339-345.

Harsono, S., Grundmann, P., Lau, L.H., Hansen, A., Salleh, M.A.M., Meyer-Aurich, A., Ghazy, T.I.M., 2013. Energy balances, greenhouse gas emissions and economics of biochar production from empty fruit bunches of oil palm. Resources, Conservation and Recycling, 77, 108-115.

Haryati, Z., Loh, S.K., Bachmann, R.T., 2016. Production and Characterization of Biochar from Palm Kernel (PKS). In 4th Asian Conference on Biomass Science, At Universiti Sains Malaysia, Bayan Lepas Penang (p. 122). Bayan Lepas.

Haya, B.A., Abdullah, M.Y., Tajarudin, N.K., 2017. The effects of oil palmres empty fruit bunch compost with hexaconazole on biomass production and nutrient contents of sweet potato var. VitAto cultivated on sandy soil. Australian Journal of Crop Science, 11(1), 83-94.

Hock, L., Baharuddin, A.S., Ahmad, M.N., Shah, U.K.M., Rahman, N.A.A., Abd-Aziz, S., Hassan, M.A., Shirai, Y. 2009. Physicochemical changes in windrow cocomposting process of oil palm mesocarp fiber and palm oil mill effluent anaerobic sludge. Australian Journal of Basic and Applied Sciences, 3(3), pp.2809-2816.

Hoe, T.K., 2014. Utilisation of Oil Palm Fruits Mesocarp Fibres Waste as Growing Media for Banana Tissue Culture Seedling in Malaysia, Journal of Advanced Agricultural Technologies, 1(1), 52-55. 
Hooi, K.K., Alimuddin, Z., Alauddin, Z., Ong, L.I.M.K., 2009. Laboratory-scale pyrolysis of oil palm pressed fruit fibres. Journal of Oil Palm Research, 21, 577587.

Ibitoye, S., Onje, S. O., 2013. Economic Analysis of Oil Palm Fruit Processing In Dekina Local Government Area of Kogi State, Nigeria. Academia Arena, 5(11), 65-73.

Idris, J., Shirai, Y., Anduo, Y., Ali, A.A.M., Othman, M.R., Ibrahim, I., Hassan, M.A., 2015. Improved yield and higher heating value of biochar from oil palm biomass at low retention time under self-sustained carbonisation. Journal of Cleaner Production, 104, 475-479.

Idris, J., Shirai, Y., Ando, Y., Ali, A.A. M., Othman, M.R., Ibrahim, I., Hassan, M.A., 2014. Production of Biochar with High Mineral Content from Oil Palm Biomass. The Malaysian Journal of Analytical Sciences, 18(3), 700-704.

Idris, S.S., Rahman, N.A., Ismail, K., 2012. Combustion characteristics of Malaysian oil palm biomass, sub-bituminous coal and their respective blends via thermogravimetric analysis (TGA). Bioresource Technology, 123, 581-591.

Index mundi. 2017. Palm oil production by country. http://www.indexmundi.com/agriculture/?commodity=palm-oil\&graph=production (accessed: 19 May 2017).

Jagustyn, B., Patyna, I., Skawińska, A., 2013. Evaluation of physicochemical properties of Palm Kernel Shell as agro biomass used in the energy industry. Chemik, 67(6), 552-559.

Jamaluddin, M.A., Ismail, K., Mohd Ishak, M.A., Ab Ghani, Z., Abdullah, M.F., Safian, M.T.U., Mohd Hakimi, N.I.N., 2013. Microwave-assisted pyrolysis of palm kernel shell: Optimization using response surface methodology (RSM). Renewable Energy, 55, 357-365.

Kabir, G., Din, A.T.M., Hameed, B.H., 2017. Pyrolysis of oil palm mesocarp fiber and palm frond in a slow-heating fixed- bed reactor: A comparative study. Bioresource Technology, 241, pp.563-572. 
Khanday, W.A., Kabir, G., Hameed, B.H., 2016. Catalytic pyrolysis of oil palm mesocarp fibre on a zeolite derived from low-cost oil palm ash. Energy Conversion and Management, 127, pp.265-272.

Kim, S.J., Jung, S.H., Kim, J.S., 2010. Fast pyrolysis of palm kernel shells: influence of operation parameters on the bio-oil yield and the yield of phenol and phenolic compounds, Bioresource Technology, 101, 9294-9300.

Kimble, M., Pasdeloup, M.V., Spencer, C., 2008. Biomass conversion technologies in Arris, L. Lang, A. Spellman, J.,Tawney, L. (Eds.). Sustainable Bioenergy Development in UEMOA Member Countries. Pp. 45-56.

Kong, S.H., Loh, S.K., Bachmann, R.T., Rahim, S.A., Salimon, J. 2014. Biochar from oil palm biomass: A review of its potential and challenges. Renewable and Sustainable Energy Reviews, 39, 729-739.

Krishnan, Y., Phun, C., Bong, C., Farhana, N., 2016. Co-composting of palm empty fruit bunch and palm oil mill ef fluent: Microbial diversity and potential mitigation of greenhouse gas emission. Journal of Cleaner Production, 146, 1-7.

Lahijani, P., Alimuddin, Z., Rahman, A., Mohammadi, M., 2013. Ash of palm empty fruit bunch as a natural catalyst for promoting the $\mathrm{CO}_{2}$ gasification reactivity of biomass char. Bioresource Technology, 132, 351-355.

Lahijani, P., Zainal, Z.A., 2011. Gasification of palm empty fruit bunch in a bubbling fluidized bed: A performance and agglomeration study. Bioresource Technology, 102(2), 2068-2076.

Lee, X.J., Lee, L.Y., Gan, S., Thangalazhy-Gopakumar, S., Ng, H.K., 2017a. Biochar potential evaluation of palm oil wastes through slow pyrolysis: Thermochemical characterization and pyrolytic kinetic studies. Bioresource Technology, 236, 155-163.

Lee, S.C.K., Rosenani, A.B., Ishak, C.F., Idris, A., Abdul Rahim, K., Meyer-Aurich, A., 2017b. 15N-labelled fertiliser recovery by maize (Zea mays L.) and leaching of nutrients as influenced by oil palm empty fruit bunch biochar in a minilysimeter under controlled tropical environment. Archives of Agronomy and Soil 
Lee, Y., Park, J., Ryu, C., Gang, K.S., Yang, W., Park, Y.K., Hyun, S., 2013. Comparison of biochar properties from biomass residues produced by slow pyrolysis at $500{ }^{\circ} \mathrm{C}$. Bioresource Technology, 148, 196-201.

Lim, P.N., Wu, T.Y., Clarke, C., Nik Daud, N.N., 2015. A potential bioconversion of empty fruit bunches into organic fertiliser using Eudrilus eugeniae. International Journal of Environmental Science and Technology, 12, 2533-2544.

Lin, C.Y., 2009. Study on Effective Utilisation of Palm Oil Waste (Empty Fruit Bunch) System in Malaysia. System in Malaysia, 3, 1-4.

Mašek, O., Brownsort, P., Cross, A., Sohi, S., 2010. Influence of production conditions on the yield and environmental stability of biochar and environmental stability. Fukuoka 5-8 December 2010. The Second International Symposium on Gasification and its Application.

Mohammad, N., Alam, M.Z., Kabbashi, N.A., Ahsan, A., 2012. Effective composting of oil palm industrial waste by filamentous fungi: A review. Resources, Conservation and Recycling, 58, 69-78.

Mohammed, M.A.A., Salmiaton, A., Wan Azlina, W.A.K.G., Mohamad Amran, M.S., 2012. Gasification of oil palm empty fruit bunches: A characterization and kinetic study. Bioresource Technology, 110, 628-636.

Moradi, A., Sung, C.T.B., Joo, G.K., Mohd Hanif, A.H., Ishak, C.F., 2015. Effect of four soil and water conservation practices on soil physical processes in a nonterraced oil palm plantation. Soil and Tillage Research, 145, 62-71.

Moradi, A., Teh, C.B.S., Goh,K.J., Husni, M.H.A., Ishak, C.F., 2014. Decomposition and nutrient release temporal pattern of oil palm residues. Annals of Applied Biology, 164, 208-219.

Moradi, A., Sung, C.T.B, Joo, G.K., Mohd Hanif, A.H., Ishak, C.F., 2012. Evaluation of Four Soil Conservation Practices in a Non-Terraced Oil Palm Plantation. Agronomy Journal, 104(6), 1727-1740. 
Nahrul Hayawin, Z., Abdul Khalil, H.P.S., Jawaid, M., Hakimi Ibrahim, M., Astimar, A. A., 2010. Exploring chemical analysis of vermicompost of various oil palm fibre wastes, Environmentalist, 30, 273-278.

Nam, W.L., Su, M.H., Phang, X.Y., Chong, M.Y., Liew, R.K., Ma, N.L., Lam, S.S. 2018. Production of bio-fertilizer from microwave vacuum pyrolysis of waste palm shell for cultivation of oyster mushroom (Pleurotus ostreatus). Science of the Total Environment, 624, 9-16.

Nutongkaew, T., Duangsuwan, W., Prasertsan, S., Prasertsan, P., 2014. Physicochemical and biochemical changes during composting of different mixing ratios of biogas sludge with palm oil mill wastes and biogas effluent. Journal of Material Cycles and Waste Management, 16, 131-140.

Ogi, T., Nakanishi, M., Fukuda, Y., Matsumoto, K., 2013. Gasification of oil palm residues (empty fruit bunch) in an entrained-flow gasifier, Fuel, 104, 28-35.

Ohimain, E.I, Izah, S.C., Obieze, F.A.U., 2013. Material-mass Balance of Smallholder Oil Palm Processing in the Niger Delta, Nigeria. Advance Journal of Food Science and Technology, 5(3), 289-294.

Ojeniyi, S.O., Awanlemhen, B.E., Adejoro, S.A., 2010. Soil Plant Nutrients and Maize Performance as Influenced by Oilpalm Bunch Ash plus NPK Fertiliser. Journal of American Science, 6(12), 456-460.

Ojeniyi, S.O., Ezekiel, P.O., Asawalam, D.O., Awo, A.O., Odedina, S., Odedina, J. N., 2009. Root growth and NPK status of cassava as influenced by oil palm bunch ash, African Journal of Biotechnology, 8(18), 4407-4412.

Olagunju, F., 2008. Economics of palm oil processing in Southwestern Nigeria. International Journal of Agricultural Economics and Rural Development, 1(2), 69-77.

Omar, R., Idris, A., Yunus, R., Khalid, K., Aida Isma, M.I., 2011. Characterization of empty fruit bunch for microwave-assisted pyrolysis. Fuel, 90, 1536-1544.

Puig-Arnavat, M., Bruno, J.C., Coronas, A., 2010. Review and analysis of biomass gasification models. Renewable and Sustainable Energy Reviews, 14, 2841- 
Ravoof, A.A.,1988. Crop production in sand with oil palm empty fruit bunch mulching, In S. Radhakrishna, M. Singh and C. K. John (Eds.), Proceedings of the 2nd Asian conference on technology for rural development, Kuala Lumpur, Malaysia, 4-7 December 1985 Kuala Lumpur, pp. 657-670.

Razali, W.A.W., Baharuddin, A.S., TarmezeeTalib, A., Sulaiman, A., Naim, M.N., Hassan, M.A., Shirai, Y., 2012. Degradation of oil palm empty fruit bunches (OPEFB) fibre during composting process using in-vessel composter. BioResources, 7(4), 4786-4805. A.

Rickson, R.J., Deeks, L.K., Graves, A., Harris, J.A.H., Kibblewhite, M.G., Sakrabani, R., 2015. Input constraints to food production: the impact of soil degradation. Food Security, 7, 351-364.

Rosenani A.B., Hoe S.F. 1996. Decomposition of oil palm empty fruit bunches in the field and mineralization of nitrogen. In: Van Cleemput O., Hofman G., Vermoesen A. (eds) Progress in Nitrogen Cycling Studies. Developments in Plant and Soil Sciences, vol 68. Springer, Dordrecht.

Rupani, P., Ibrahim, M., Ismail, S., 2013. Vermicomposting biotechnology: recycling of palm oil mill wastes into valuable products. International Journal Of Recycling of Organic Waste in Agriculture, 2(1), 10.

Rupani, P.F., Singh, R.P., Ibrahim, M.H., Esa, N., 2010. Review of Current Palm Oil Mill Effluent (POME) Treatment Methods: Vermicomposting as a Sustainable Practice. World Applied Sciences Journal, 10(10), 1190-1201.

Sabrina, D.T., Gandahi, A.W., Hanafi, M.M., Mahmud, T.M.M., Nor Azwady, A.A., 2012. Oil palm empty-fruit bunch application effects on the earthworm population and phenol contents under field conditions. African Journal of Biotechnology, 11(19), 4396-4406.

Sabrina, D.T., Hanafi, M.M., Mahmud, T.M.M., Azwady, A.A.N., 2011. Evaluation of Nutrients Released from Phosphorus-Enriched Empty Oil Palm Fruit Bunches As Growing Media Using Setaria splendida. Compost Science and Utilisation, 
Sabrina, D.T., Hanafi, M.M., Mahmud, T.M.M., Nor Azwady, A.A., 2009. Vermicomposting of Oil Palm Empty Fruit Bunch and its Potential in Supplying of Nutrients for Crop Growth. Compost Science and Utilisation, 17(1), 61-67.

Shafawati, S N., Siddiquee, S. 2013. Composting of oil palm fibres and Trichoderma spp. as the biological control agent: A review. International Biodeterioration \& Biodegradation, 85, 243-253.

Shariff, A., Aziz, N.S.M., Abdullah, N. 2014. Slow Pyrolysis of Oil Palm Empty Fruit Bunches for Biochar Production and Characterisation. Journal of Physical Science, 25(2), 97-112.

Siddiquee, S., Shafawati, S.N., Naher, L., 2017. Effective composting of empty fruit bunches using potential Trichoderma strains. Biotechnology Reports, 13, 1-7.

Siddiqui, Y., Meon, S., Mohd, R.I., RAhmani, M., Ali, A., 2009. Efficient Conversion of Empty Fruit Bunch of Oil Palm Into Fertiliser Enriched Compost. Asian Journal of Microbiology, Biotech. Envi. Sc., 11(2), 1-6.

Singh, R.P., Embrandiri, A., Ibrahim, M.H., Esa, N., 2011. Management of biomass residues generated from palm oil mill: Vermicomposting a sustainable option. Resources, Conservation and Recycling, 55, 423-434.

Sridhar and AdeOluwa, 2009. Palm Oil Industry Residues, in: Singh nee' Nigam, P., Pandey, A. (Eds.), Biotechnology for Agro-Industrial Residues Utilisation. Springer, Dordrecht Netherlands, pp.341-355

Sukiran, M.A., Kheang, L.S., Bakar, N.A., May, C.Y., 2011. Production and Characterization of Bio-Char from the Pyrolysis of Empty Fruit Bunches. American Journal of Applied Sciences, 8(10), 984-988.

Sulaiman, F. and Abdullah, N., 2011. Optimum conditions for maximising pyrolysis liquids of oil palm empty fruit bunches. Energy, 36, 2352-2359.

Sulaiman, F., Abdullah, N., Gerhauser, H., Shariff, A., 2011. An outlook of Malaysian energy, oil palm industry and its utilisation of wastes as useful resources. 
Sung, C.T.B., Joo, G.K., Kamarudin, K.N., 2010. Physical changes to oil palm empty fruit bunches (EFB) and EFB mat (Ecomat) during their decomposition in the field. Pertanika Journal of Tropical Agricultural Science, 33(1), 39-44.

Tabi, A.N.M., Zakil, F.A., Fauzai, W.N.F.M., Ali, N., Hassan, O., 2008. The Usage of Empty Fruit Bunch (EFB) and Palm Pressed Fibre (PPF) as Substrates for the Cultivation of Pleurotus ostreatus. Jurnal Teknologi, 49(F), 189-196.

Thambirajah, J.J., Kuthubutheen, A.J.,1989. Composting of palm press fibre. Biological Wastes, 27, 257-269.

Van Eijk, R.J., Obernberger, I., Supancic, K., 2012. Options for increased utilization of ash from biomass combustion and co-firing. IEA Bioenergy Task 32 Deliverable D4, Arnhem.

Vijaya, S., Ma, A.N., Choo, Y.M., Meriam, N.I.K. 2008. Life Cycle Inventory of the Production of Crude Palm Oil - a Gate To Gate Case Study of 12. Journal of Oil Palm Research, 20(June), 484-494.

Wilson, L., Yang, W., Blasiak, W., John, G.R., Mhilu, C.F., 2011. Thermal characterization of tropical biomass feedstocks, Energy Conversion and Management, 52, 191-198.

Xu, X., Zhao, Y., Sima, J., Zhao, L., Mašek, O., Cao, X., 2017. Indispensable role of biochar-inherent mineral constituents in its environmental applications: A review, Bioresource Technology, 241, 887-899.

Yahya, A., Sye, C.P., Ishola, T.A. and Suryanto, H., 2010. Effect of adding palm oil mill decanter cake slurry with regular turning operation on the composting process and quality of compost from oil palm empty fruit bunches. Bioresource Technology, 101, 8736-8741.

Yeoh, C.Y., Chin, N.L., Tan, C.S., 2011. Co-composting of palm oil mill wastes. Journal of Food Agriculture Environment, 9(3\&4), 880-2011.

Yusoff, S., 2006. Renewable energy from palm oil - innovation on effective utilisation 

of waste. Journal of Cleaner Production, 14, 87-93.

1011 Zaharah, A.R., Lim, K.C., 2000. Oil palm empty fruit bunch as a source of nutrients 1012 and soil ameliorant in oil palm plantations. Malaysian Journal of Soil Science, 4, $1013 \quad 51-66$

1014 Zainal, N.H., Aziz, A.A., Idris, J., Mamat, R., Hassan, M.A., Bahrin, E.K., Abd-Aziz, 1015 S., 2016. Microwave-assisted pre-carbonisation of palm kernel shell produced 1016 charcoal with high heating value and low gaseous emission. Journal of Cleaner Production, 142, 2945-2949.

1018 Zhao, L., Cao, X., Mašek, O., Zimmerman, A., 2013. Heterogeneity of biochar 1019 properties as a function of feedstock sources and production temperatures. 1020 Journal of Hazardous Materials, 256-257, 1-9. 